\title{
CORPORATE SOCIAL RESPONSIBILITY INDEX FOR UKRAINIAN BANKS: THE ESSENTIALS FOR IMPLEMENTATION
}

\author{
Alexander Kostyuk*, Olena Kostyuk**, Yaroslav Mozghovyi***, Yana Kravchenko***** \\ * Department of International Economics, Ukrainian Academy of Banking of the National Bank of Ukraine \\ E-mail: alex_kostyuk@virtusinterpress.org \\ ** Department of International Economics, Ukrainian Academy of Banking of the National Bank of Ukraine \\ *** Department of International Economics, Ukrainian Academy of Banking of the National Bank of \\ Ukraine \\ E-mail:ㄲozghovyi@gmail.com \\ **** Hanken School of Economics, Finland, \\ E-mail: yana.kravchenko.ua@mail.ru
}

\begin{abstract}
The aim of this paper is to solve the problem of CSR performance measurement for Ukrainian banking institutions by developing a CSR index. It is done by measuring a corporate social responsibility (CSR) through 25 different indicators for 40 Ukrainian banks, which represent $80 \%$ of total banking system assets. This paper is a first attempt in Ukrainian practice to put CSR indicators into a standard metrics and develop specific methodology that would allow comparing CSR for different banks. To check the adequacy of our preliminary findings we compare CSR results for Ukrainian banks with CSR results for Swedish banks, where the level of CSR is definitely higher, since it is a socially directed developed economy. After that the weights of CSR index for Swedish banks counted by our methodology was compared to different professionally made indexes.
\end{abstract}

Keywords: Corporate Social Responsibility, CSR performance measurement, Index, Banks, Ukraine, Sweden

\section{Introduction}

The concept of the corporate social responsibility (CSR) has been developed since the first part of the XX century by many world known economists. Importance and significance of the CSR for all kinds of firms and corporations became obvious many years ago.

Organizations are being called upon to take responsibility for the ways their operations influence societies and the environment. The type of relationships that a company has with its employees, customers, investors and government determines success of its operations in general. Thus, companies are also being asked to apply sustainability principles to the ways in which they conduct their businesses.

Many scientific papers mentioned the view that CSR can contribute to the corporate financial performance (CFP) of a company. However, there is currently a debate on the extent to which CSR 
influences a CFP of a company. This topic became even more prominent during the last economic and financial crisis, especially for banking institutions, since they are the key sector of market economy.

It should be mentioned that it is difficult to describe the correlation between CSR and CFP for Ukrainian banking sector, since there were no practice calculating any CSR index or measuring CSR in any mathematical way. But still, drawing on the experiences of those companies that have adopted CSR, it is undoubtedly, that good CSR activities are crucial for the company if its strategic goal is to maximize longterm financial returns. Since Ukraine did not launch yet a CSR concept fully, it would be useful to draw managers' attention to this fact. So our paper is an attempt to provoke new scientific researches and attract more attention to such important field of research.

\section{Previous studies}

Hurst N. (2004) in his study compared governance and CSR practices of corporations based in the United States and Europe. To measure similarities and differences the author took such indicators as the existence of Code of Conduct, CSR or sustainability report, the disclosure of company's conflict of interest guidelines and some others. Hurst admits that Dow Jones Sustainability Index (DJSI) is one of the most competitive indexes due to its high social, ethical, and environmental standards. Though DJSI provides objective benchmarks to manage sustainability-driven portfolios, the index is only calculated for the leading sustainability companies, leaving behind the majority of other companies. For instance, the DJSI World covers only the largest 2500 companies by market capitalization in the Dow Jones Global Index.

Boston College Center for Corporate Citizenship and Reputation Institute developed CSR Index for American companies. It is counted on an annual basis and is performed as ranking of top 50 companies with the best CSR. However, the problem lies in the absence of methodology of how the index is calculated. Also, it is calculated only for American companies. All above-mentioned makes it impossible to compare this index with other ones and calculate it for non-American companies.

According to Lockett et al. (2006), there are some peculiarities for CSR measurement in developed and in developing countries. He states that in developed countries the CSR literature is dominated by quantitative methods (80\%), whereas CSR papers on developing countries are more likely to be qualitative.

Dimtcheva, Marsland and Morrison (2002) published report, where analyzed socially responsible investing in the context of the choice of benchmark and briefly compared the Dow Jones Sustainability Index and FTSE4Good Index. FTSE4Good, a UK-based index, developed with Ethical Investment Research Service (EIRIS), evaluates a company's commitment to SR by examining the environment, human rights and stakeholder relationships. Unfortunately, index includes companies with progressing practices of SR, excluding companies with controversial activities. Another criteria due to which companies fail to be included in FTSE4Good is lack of data. So FTSE still have to work together with EIRIS to overcome such problem and make its index more competitive. It was concluded that the main difference between the two SRI benchmarks is that FTSE4Good Indices are based on the exclusion methodology (negative screening) and DJSI are based on the "bestin-class" approach (positive screening). 
Mitchell, Holt, Swartz, Kido, Song and Kolind (2004) reviewed existing sustainable metrics. Researched showed that many existing indices are not independent and do not provide an objective measure of sustainability. The authors chose five indices: Dow Jones Sustainability Index (DJSI), Ethibel, FTSE4Good, Domini 400 Social Index and Vanguard Calvert Social Index Fund, that according to them provided the most comprehensive evaluation of sustainable practices and then analyzed the indicators used by each index in their evaluation and compared the companies $d$ that tin each index. As a result, some similarities and differences were identified across indices but according to the authors the indices and metrics we reviewed were vague and provided little tangible metrics to evaluate.

Overall, we came up with clear vision that already existing indices do not provide enough information about their methodologies, thus we can conclude that they don't have much meaning without full transparency. Even CSR rankings groups that publish their methodologies rarely offer enough sufficient information to determine what differentiates their indices from others. So taking all these facts into account we decided that it would be useful to develop our own CSR Index that would on the one hand have a clear and open methodology, on the other - would rely on such information that could be easily accessed for the majority of companies all over the world, including Ukrainian ones.

\section{Methodology}

\section{1 Index components}

As a basis for our CSR index was chosen one of the most fundamental and most cited works in this sphere - "The Pyramid of Corporate Social Responsibility: Toward the Moral Management of Organizational Stakeholders" by A. Carroll [5]. In this work A. Carroll presented his pyramid of the CSR that is some kind of analogue of Maslow's hierarchy of needs.

The pyramid consists of 4 levels. Their priority is reducing from the bottom to the top. It is suggested that four kinds of social responsibilities constitute total CSR: economic, legal, ethical and philanthropic. Among these levels of CSR we have picked up those parameters that could be easily indicated through the websites of the analyzed institutions and annual reports etc. On the next stage of the research we've tried to simplify the methodology even more. To exclude the subjectivity and possible unprofessionalism from the research we decided that we will assess only the presence or absence of different parameters in the banking activity with the help of the dummy variables like " 0 " or " 1 ". At the end index of CSR will appear in the form of the total number of the variables.

So the first level of the pyramid is presented by economic responsibilities. Carroll writes that historically business organizations were created as economic entities designed to provide goods and services to societal members. The profit motive was established as the primary incentive for entrepreneurship. Before it was anything else, business organization was the basic economic unit in our society. At some point the idea of the profit motive got transformed into a notion of maximum profits, and this has been an enduring value ever since. All other business responsibilities are predicated upon the economic responsibility of the 
firm, because without it the others become moot considerations. Table 1 summarizes some important statements characterizing economic responsibilities [5].

Table 1. Economic and Legal Components of Corporate Social Responsibility

\begin{tabular}{|c|c|}
\hline & \\
\hline $\begin{array}{l}\text { 1. It is important to perform in a manner consistent } \\
\text { with maximizing earnings per share } \\
\text { 2. It is important to be committed to being as } \\
\text { profitable as possible. } \\
\text { 3. It is important to maintain a strong competitive } \\
\text { position. } \\
\text { 4. It is important to maintain a high level of } \\
\text { operating efficiency. } \\
\text { 5. It is important that a successful firm be defined as } \\
\text { one that is consistently profitable. }\end{array}$ & $\begin{array}{l}\text { 1. It is important to perform in a manner consistent } \\
\text { with expectations of government and law. } \\
\text { 2. It is important to comply with various federal, } \\
\text { state, and local regulations. } \\
\text { 3. It is important to be a law-abiding corporate } \\
\text { citizen. } \\
\text { 4. It is important that a successful firm be defined as } \\
\text { one that fulfills its legal obligations. } \\
\text { 5. It is important to provide goods and services that } \\
\text { at least meet minimal legal requirements. }\end{array}$ \\
\hline
\end{tabular}

From the first level of the pyramid we've included into the index parameter of profit and paid dividends. They should represent responsibility to shareholders. Taxes paid by bank are also included into the economic level and represent responsibility to the country. This level of responsibility is generally accepted and should be fulfilled by the majority of the banks.

Next level refers to the legal responsibilities that are also depicted in the Table 2. According to Carroll society has not only sanctioned business to operate according to the profit motive; at the same time business is expected to comply with the laws and regulations promulgated by federal, state, and local governments as the ground rules under which business must operate. As a partial fulfillment of the "social contract" between business and society firms are expected to pursue their economic missions within the framework of the law. Legal responsibilities reflect a view of "codified ethics" in the sense that they embody basic notions of fair operations as established by our lawmakers. They are depicted as the next layer on the pyramid to portray their historical development, but they are appropriately seen as coexisting with economic responsibilities as fundamental precepts of the free enterprise system [5].

On this level we have picked up only two parameters: regulative compliance (fulfillment capital requirements, risk requirements, different resolutions and decree and absence of the not obidance record in the examined period); law obedience (fulfillment of the general law requirements, absence of public scandals etc.).

The third level of CSR according to Carroll is represented by ethical responsibilities. Although economic and legal responsibilities embody ethical norms about fairness and justice, ethical responsibilities embrace those activities and practices that are expected or prohibited by societal members even though they are not codified into law. Ethical responsibilities embody those standards, norms, or expectations that reflect 
a concern for what consumers, employees, shareholders, and the community regard as fair, just, or in keeping with the respect or protection of stakeholders' moral rights.

The business ethics movement of the past decade has firmly established an ethical responsibility as a legitimate CSR component. Though it is depicted as the next layer of the CSR pyramid, it must be constantly recognized that it is in dynamic interplay with the legal responsibility category. That is, it is constantly pushing the legal responsibility category to broaden or expand while at the same time placing ever higher expectations on businesspersons to operate at levels above that required by law [5]. It is like that in developed countries. But in developing countries laws a mainly directed on satisfying needs in legal economic activity and do not refer to the ethical issues. That's why some parameters included by us in this segment belong to the sphere of legal responsibilities in developed countries, but in Ukraine they are purely ethical.

Ethical level of responsibilities obtains by proposed in this paper methodology the biggest quantity of parameters because by our point of view it shows social intentions of the company most eloquently. It is not obligatory, like previous two and not so populist like the last level - philanthropic. Ethical level consists of responsibilities directed to different stakeholders of the company: employees - existence of the compensation that exceeds the average in the sector, and programs that support professional and individual development, provide competitive and comfortable working environment; shareholders, customers, partners and general public that could be provided by the information disclosure and quality of the information on the company's activity (remuneration disclosure, information on the board of directors and top management, availability of the information to all groups of stakeholders, existence of the separate report on CSR, reporting according Global Reporting Initiative or other socially directed standards), by the environmental responsibility of the company (although this issue for financial institutions is not so critical and important as for the industrial companies, banks could show good example and provide public initiatives on environmental responsibility to its customers, partners, competitors), by making of the socially responsible investments (this segment of the investments is a fast growing sector that controls at the moment several trillions USD in funds, banks as active financial players could sufficiently support it by own activity directed like on the profit seeking purposes and at the same time on the social projects. We have also regarded in this category providing of the socially responsible loans, with environmental and social conditions). Table 2 depicts statements that help characterize ethical responsibilities. The figure also summarizes philanthropic responsibilities, discussed next.

Table 2. Ethical and Philanthropic Components of Corporate Social Responsibility

\begin{tabular}{|r|c|}
\hline \multicolumn{1}{|c|}{ Ethical Components (Responsibilities) } & Philanthropic Components (Responsibilities) \\
\hline $\begin{array}{r}\text { 1. It is important to perform in a manner consistent } \\
\text { with expectations of societal mores and ethical }\end{array}$ & $\begin{array}{c}\text { 1. It is important to perform in a manner consistent } \\
\text { with the philanthropic and charitable } \\
\text { expectations of society. }\end{array}$ \\
$\begin{array}{r}\text { norms. } \\
\text { 2. It is important to recognize and respect new or } \\
\text { evolving ethical moral norms adopted by society. }\end{array}$ & $\begin{array}{c}\text { 2. It is important to assist the fine and performing } \\
\text { arts. }\end{array}$ \\
\hline
\end{tabular}




\begin{tabular}{|l|r|}
$\begin{array}{l}\text { 3. It is important to prevent ethical norms from being } \\
\text { compromised in order to achieve corporate } \\
\text { goals. }\end{array}$ & $\begin{array}{r}\text { 3. It is important that managers and employees } \\
\text { participate in voluntary and charitable activities } \\
\text { within their local communities. }\end{array}$ \\
$\begin{aligned} \text { 4. It is important that good corporate citizenship be } \\
\text { defined as doing what is expected morally or } \\
\text { ethically. }\end{aligned}$ \\
$\begin{aligned} \text { 5. It is important to provide assistance to private and } \\
\text { public educational institutions. } \\
\text { and ethical behavior go beyond mere compliance } \\
\text { with laws and regulations. }\end{aligned}$ \\
$\begin{array}{l}\text { 5. It is important to assist voluntarily those projects } \\
\text { that enhance a community's "quality of life." }\end{array}$
\end{tabular}

The last fourth level of CSR is represented according to Carroll by philanthropic responsibilities. He wrote that philanthropy encompasses those corporate actions that are in response to society's expectation that businesses be good corporate citizens. This includes actively engaging in acts or programs to promote human welfare or goodwill. Examples of philanthropy include business contributions to financial resources or executive time, such as contributions to the arts, education, or the community.

The distinguishing feature between philanthropy and ethical responsibilities is that the former are not expected in an ethical or moral sense. Communities desire firms to contribute their money, facilities, and employee time to humanitarian programs or purposes, but they do not regard the firms as unethical if they do not provide the desired level. Therefore, philanthropy is more discretionary or voluntary on the part of businesses even though there is always the societal expectation that businesses provide it.

One notable reason for making the distinction between philanthropic and ethical responsibilities is that some firms feel they are being socially responsible if they are just good citizens in the community. This distinction brings home the vital point that CSR includes philanthropic contributions but is not limited to them. In fact, it would be argued here that philanthropy is highly desired and prized but actually less important than the other three categories of social responsibility [5].

On this level of CSR we've picked up such parameters as philanthropic activity of the company in general, arts support, education and research support, and volunteering activity of the staff.

Except of the CSR four levels Carroll also describes the way of management that reflects CSR in best way. It is called "moral management". Its main features applied to different groups of stakeholders are represented in Table 3.

Table 3. Main features of the Carroll's moral management oriented toward different stakeholders

\begin{tabular}{|l|l|}
\hline \multicolumn{1}{|c|}{ Group of stakeholders } & \multicolumn{1}{|c|}{ Features } \\
\hline $\begin{array}{l}\text { Orientation Toward } \\
\text { Owner/Shareholder Stakeholders }\end{array}$ & $\begin{array}{l}\text { Shareholders' interest (short- and long-term) is a central factor. The } \\
\text { best way to be ethical to shareholders is to treat all stakeholder } \\
\text { claimants in a fair and ethical manner. To protect shareholders, an } \\
\text { ethics (or CSR) committee of the board is created. Code of ethics is } \\
\text { established, promulgated, and made a living document to protect }\end{array}$ \\
\hline
\end{tabular}




\begin{tabular}{|l|l|}
\hline $\begin{array}{l}\text { Orientation Toward Employee } \\
\text { Stakeholders }\end{array}$ & $\begin{array}{l}\text { Employees are a human resource that must be treated with dignity and } \\
\text { respect. Goal is to use a leadership style such as } \\
\text { consultative/participative that will result in mutual confidence and } \\
\text { trust. Commitment is a recurring theme. Employees' rights to due } \\
\text { process, privacy, freedom of speech, and safety are maximally } \\
\text { considered in all decisions. Management seeks out fair dealings with } \\
\text { employees. }\end{array}$ \\
\hline $\begin{array}{l}\text { Orientation Toward Customer } \\
\text { Stakeholders }\end{array}$ & $\begin{array}{l}\text { Customer is viewed as equal partner in transaction. Customer brings } \\
\text { needs/expectations to the exchange transaction and is treated fairly. } \\
\text { Managerial focus is on giving customer fair value, full information, } \\
\text { fair guarantee, and satisfaction. Customer rights are liberally } \\
\text { interpreted and honored. }\end{array}$ \\
\hline Orientation Toward Local & $\begin{array}{l}\text { Sees vital community as a goal to be actively pursued. Seeks to be a } \\
\text { leading citizen and to motivate others to do likewise. Gets actively } \\
\text { involved and helps institutions that need help-schools, recreational } \\
\text { groups, and philanthropic groups. Leadership position in environment, } \\
\text { education, culture/arts, volunteerism, and general community affairs. } \\
\text { Firm engages in strategic philanthropy. Management sees community } \\
\text { goals and company goals as mutually interdependent. }\end{array}$ \\
\hline
\end{tabular}

Taking into account Carroll's moral management concept we have decided to include into index some more components (that were not included in previous four levels). Several of them are connected with the risk management and orientation towards the stakeholders.

Managing risk is a central part of many corporate strategies. Reputations that take decades to build up can be ruined in hours through incidents such as corruption scandals or insolvency crisis in bank. These can also draw unwanted attention from regulators, courts, governments and media. Building a genuine culture of 'doing the right thing' within a corporation can offset these risks. ${ }^{1}$

Levine (2008) highlights managing risks as a main benefit of CSR in the short-term: "Why implement a CSR program? In short, to manage risks and to ensure legal compliance companies may be exposed to a variety of legal and reputation risks if they do not have adequate social compliance or CSR/sustainability programs in place" (2008: 2 ).

But financial risks on the contrary of the non financial risks, form the core of the bank's management. Moreover, we should consider that CSR and CFP in bank are closely tight not only to the reputational risks but also to the effectiveness of the financial risk management and control process. This is why we put the risk issue under consideration in terms of its management and control.

\footnotetext{
${ }^{1}$ Kytle, Beth; (2005). "Corporate Social Responsibility as Risk Management: A Model for Multinationals"
} 
Risk issue is one of the questions Basel Committee works on. In March 2010 The Basel Committee published a consultative document "Principles for enhancing corporate governance", where the main recommendations about risk management in banks were stated. According to The Basel "Large banks and internationally active banks, and others depending on their risk profile and local governance requirements, should have an independent senior executive with distinct responsibility for the risk management function and the institution's comprehensive risk management framework across the entire organization. This executive is commonly referred to as the chief risk officer (CRO)." Mentioned document highlights the necessity of the external risk control infrastructure in the bank.

We suppose that risk controlling process could be executed more effectively on the level of Board of Directors, who plays the crucial role in risk management as the main body of decision making process of the bank.

Pursuant to the Third King Report on Governance 2009, the formed Board of Directors must:

- take into account not only financial indicators, but also the impact of the company's activities on society and environment;

- protect and invest in welfare of the economy, society, and environment;

- ensure the company's actions and cooperation with stakeholders based on the law;

- take into account the need for joint efforts with stakeholders in order to promote ethical conduct and good corporate governance;

- provide measurability of implemented CSR programs;

- be aware that the strategy, risk, indicators, and sustainability are inseparable and consider sustainability as business opportunity;

- ensure efficient governance based on ethical principles;

- contribute to the company remaining and being considered a responsible corporate citizen;

- the company has an efficient and independent audit committee whose duties include audit of both financial and non-financial statements.

It should be mentioned, that control functions can't be objectively executed by the internal employee. The position of the controlling director must be taken by the independent person. Moreover, the tendency to hire independent directors is on the rise with the purpose of improving quality of decisions made at the level of the Board who have different experience, skills, knowledge, and expertise which means "diversity" in the CSR language. This aspect ensures more reasonable decisions concerning financial and non-financial issues and brings about positive results.

We also consider that independent directors could better execute their functions in risk management process and CSR activity of the bank, if they are grouped in profile collegiate bodies, such as committees of the Board. Among the committees which effect bank's CSR policy we could name following: CSR committee, audit committee, corporate governance committee, risk management and control committee.

Also writing about orientation to the shareholders Carroll talks about the code of conduct [link]. Codes of conduct are mainly used as tools of corporate governance, but their usage grows for purposes of CSR with the following priority issues: 
- the company's impact on the economic, environmental, and social areas, sustainability;

- working atmosphere;

- labour relationships;

- relationships with suppliers;

- ethical conduct.

An ethics code and practices that foster transparency are the basis for a company to comply with its operational and strategic objectives. These guide companies on how to behave when managing relationships with suppliers, investors and employees. Communications and control mechanisms on compliance form part of this category.

In the CSR literature, codes of conduct are variably described and defined and have common elements, such as being self-regulatory or voluntary in nature, used to influence behavior of a specified group or groups, and/ or to define intentions/ actions on a certain group of issues or to a certain group of individuals, sometimes from a market-based perspective (Kolk, van Tulder and Welters, 1999; Kaptein and Wempe, 2002; United States Council for International Business, 2000; ILO, n.d.a; ILO, n.d.b; Forcese, 1997; Alexander, 1997; Dickerson and Hagan, 1998; OECD, 2001; Diller, 1999).

In this literature, an implicit relationship exists between codes and CSR that is well illustrated by the United States Council for International Business (USCIB) where the corporate responsibility section on their website has a recent 'position/ statement document' on codes of conduct, where codes are defined as '...commitments voluntarily made by companies, associations, or other organizations that put forth standards and principles of business conduct in the marketplace, and are thus primarily market-driven' (2000, p.2).

In some cases, this primarily implicit relationship between codes and CSR is made explicit such as with Kolk, van Tulder and Welters (1999) who define codes of conduct as '...encompass[ing] guidelines, recommendations or rules issued by entities within society (adopting body or actor) with the intent to affect the behavior of (international) business entities (target) within society in order to enhance corporate responsibility' (p.151). Other authors indicating a more explicit relationship between codes and CSR include Dickerson and Hagen (1998) and OECD (2001). As we will see later, Kolk, van Tulder and Welters (1999) make an important distinction between these 'international' codes and internal codes of conduct '...which consist of guidelines for staff on how to behave when confronted with dilemmas such as conflict of interest, gifts, theft, insider trading, pay-offs and bribery' (p.150), arguing that the internal codes do not address the business-society relationship.

Efficient code of conduct should declare information for bank personnel about right treatment of the clients. We suppose, that compliance of the rules, stated in the code provides for the bank better dialog with the clients, and thus could assist in increasing of the deposit volume that could be treated as competitive advantage of the bank and positively influence it's CFP. That's why the result of the presence of the code of conduct could be analyzed by the comparative indicator of the bank's deposits share in the total banking system deposits volume. 
So abovementioned pushed us to including into the index such parameters: independent directors in the board; committees of the board, and separately corporate governance committee, CSR committee and audit committee; code of conduct.

And final parameter that was included in to the index is CSR development by the company, which means engagement of the company into public affairs concerning CSR like conferences, workshops, informative and consultative activity etc.

For each of the proposed parameters was chosen its marking (Appendix 1).Formula 1 describes the final form of the index:

$$
\begin{aligned}
& I^{c s r}=\Sigma E^{c}\left(p, d^{p}, t^{p}\right), L^{c}\left(r^{c}, l^{o}\right), E t h\left(I^{r}, E x>a v, e s p, E n^{r}, D^{r}, D^{b d}, D^{s t}, R^{c s r}, C^{G R I}\right), \\
& P h^{r}\left(p h, a r t^{s}, e d^{s}, v a^{e m p}\right), M M^{c}\left(D^{i}, C^{b}, C^{a}, C^{c s r}, C^{c g}, C^{c}\right), S R^{d}
\end{aligned}
$$

\section{1 Research sample}

For our research and statistical analysis we've picked top 40 banks which operate on Ukrainian market whose share in assets of the whole banking system exceeds $80 \%$ so representation degree is high enough. Among them 17 are banks owned by national shareholders, we call them "resident banks" and 23 owned by foreign shareholders, we call them nonresident banks.

To identify parameters of the CSR index we've analyzed financial reports of the banks for the 2010, their websites and publicly available information. Final data on parameters was summarized according to formula 1 into one index for each institution.

To verify the adequacy of the index it was decided to check its' operation on the Swedish banks, players of the country, that has one of the most highly developed welfare states in the world. The country has a higher level of social spending to GDP than any other nation. In 2010, it was ranked fourth in the world in The Economist's Democracy Index and ninth in the United Nations' Human Development Index. In 2010, the World Economic Forum ranked Sweden as the second most competitive country in the world, after Switzerland ${ }^{2}$. So we suppose that social affairs of the Swedish banks should be on high level. After that we needed to compare rankings of the banks according to our index and according other professionally maid indexes of CSR. Into the initial sample 65 Swedish commercial banks were included.

There are several indexes of CSR that provides information on Swedish banking institutions. Among them we could indicate Dow Jones Sustainability Indexes ${ }^{3}$ that are the first global indexes tracking the financial performance of the leading sustainability-driven companies worldwide; corporate social responsibility index conducted by the Swedish insurance company Folksam ${ }^{4}$; FTSE4Good index ${ }^{5}$ and Ethibel CSR index ${ }^{6}$.

According to our hypothesis we suppose that:

\footnotetext{
${ }^{2}$ http://en.wikipedia.org/wiki/Sweden

${ }^{3} \mathrm{http}: / / \mathrm{www}$.sustainability-index.com/

${ }^{4}$ http://www.folksam.se/

${ }^{5} \mathrm{http}: / /$ www.ftse.com/Indices/FTSE4Good_Index_Series/index.jsp

${ }^{6} \mathrm{http}: / /$ forumethibel.org/content/home.html
} 
1) the results of the research will indicate the direct correlation between the size of the bank and its CSR index as in Ukraine so in Sweden;

2) nonresident banks that operate on Ukrainian market will score more points of the index than resident ones because they are influenced by the politics implemented in their mother companies

3) Ukrainian banks will score quite low (lower than the half of the maximum) that of course will be much lower of the Swedish banks result.

\section{Results}

The results of the analysis on Ukrainian banks occurred controversial. Appendix 2 contains table with index weights for all Ukrainian banks in the initial sample. Figure 2 depicts percentage of the banks that showed different results of the index.

Figure 1. Percentage of the Ukrainian banks according to different index weights

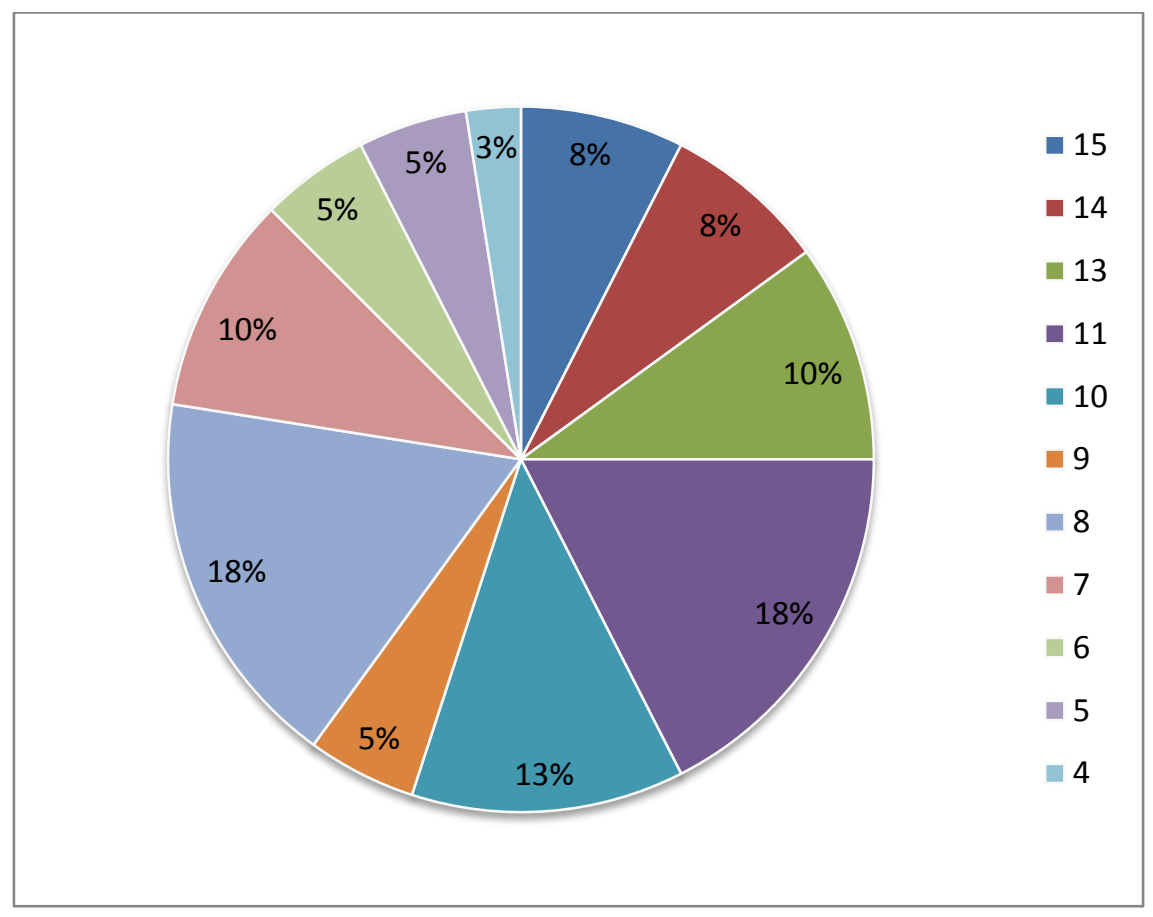

We found some correlation between the size of the bank and its corporate social performance (CSP) but it is not homogeneous and could not be taken as an absolute. The average result is "10" based on this $42,5 \%$ of all banks showed results above it and $12,5 \%$ showed exactly " 10 ".

The majority of the Ukrainian banks scored " 8 " and " 11 " points (18\% equally). The highest rank is " 15 ". Only $8 \%$ of the banks showed the best result and all of them do not belong to top 10 banks. Even in top ten not all banks scored higher than average, 3 of 10 obtained lower index. However $70 \%$ of top 20 banks scored higher than " 10 " and only $25 \%$ in lower 20 banks. Moreover their average index $(11,1)$ is higher than the average in 20 lower banks $(8,6)$. 
So our hypothesis about correlation of the banks size and CSP is partially approved because the majority of bigger banks showed better results, but some of them failed to score higher than average and some smaller banks showed results mush higher than each of top 10.

Among resident Ukrainian banks $76 \%$ scored lower than average. And average result inside the group is " 9,15 " that is lower compared to the whole sample. Nonresident banks' group average is higher " 10,4 ? and $50 \%$ of banks performed lower than average, that is $26 \%$ less, compared to resident banks (figure 2).

Figure 2. Resident and nonresident banks scorings compared to average

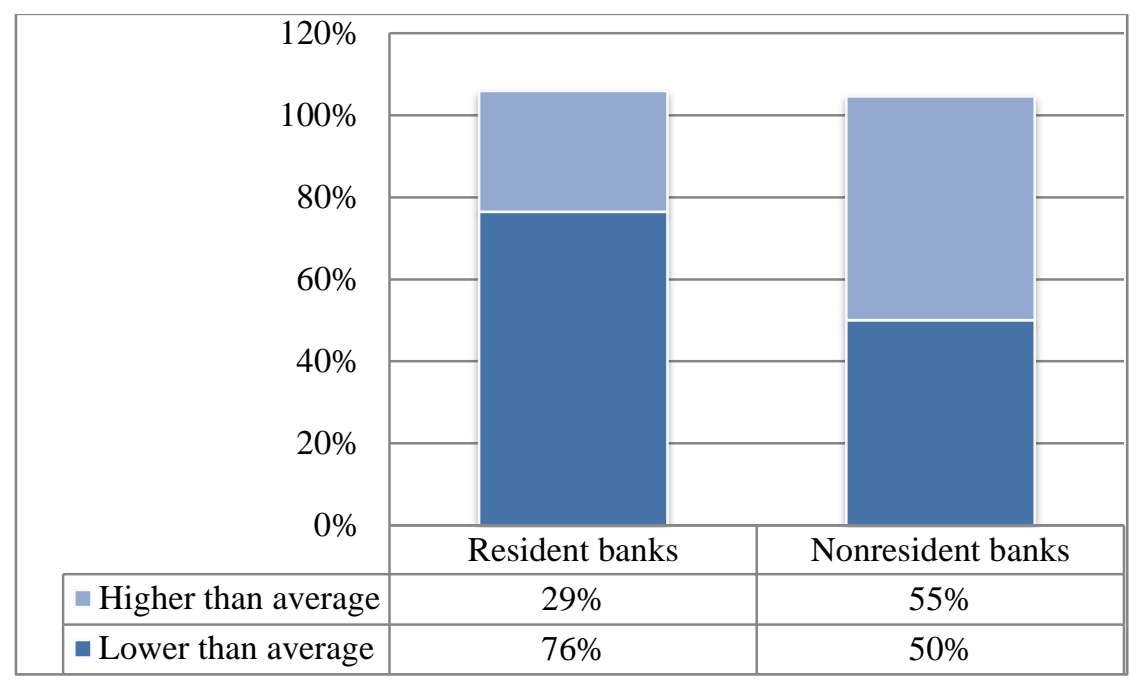

Based on the abovementioned results we could make a conclusion, that our second hypothesis about differences in CSP of resident and nonresident Ukrainian banks was confirmed. But we should admit, that the majority of nonresident banks are in top 20 ranked by size. And there is no possibility on this stage of the research to indicate which factor influences banks' CSP more: size or residence. But we conclude that both these factors in synergy made their contribution into the final result.

What about our third hypothesis we can conclude, that only $25 \%$ of the total 40 banks scored higher than the half of the maximum index weight (25), that confirm the first part of the hypothesis.

Examining Swedish banks we excluded from the initial sample:

- branches of the foreign banks;

- banks that in majority belongs to Swedbank (because they hardly have their own CSR strategy);

- former savings banks (because they operate similar and do not provide full range of services);

- banks that do not provide last financial reports on their websites or provide them only in Swedish.

So in the final sample 14 banks left (Table 4). 
Table 4. Final sample of the Swedish banks

\begin{tabular}{|c|c|l|c|}
\hline № & Size of the Balance sheet (2010) $^{7}$ & \multicolumn{1}{|c|}{ Bank name } & CSR index \\
\hline 1 & 1 & Handelsbanken & 20 \\
\hline 2 & 2 & SEB & 21 \\
\hline 3 & 3 & Nordea Bank & 21 \\
\hline 4 & 4 & Swedbank & 19 \\
\hline 5 & 6 & SBAB Bank & 19 \\
\hline 6 & 8 & Länsförsäkringar Bank & 16 \\
\hline 7 & 10 & Sparbanken Öresund & 13 \\
\hline 8 & 11 & GE Money Bank & 19 \\
\hline 9 & 12 & Volvofinans Bank & 11 \\
\hline 10 & 15 & Nordnet Bank & 13 \\
\hline 11 & 17 & Avanza Bank & 15 \\
\hline 12 & 18 & Carnegie Investment Bank & 16 \\
\hline 13 & 32 & Forex Bank & 9 \\
\hline 14 & 33 & EFG Bank & 13 \\
\hline
\end{tabular}

Results of the Swedish banks' CSR index also confirmed second part of our $3^{\text {rd }}$ hypothesis. Average CSR index among them is " 16 " and 13 from 14 banks scored higher than the average in Ukrainian sample.

Inside the group of Swedish banks same percentage - $43 \%$ of banks scored as higher so lower than the average and $14 \%$ showed exactly middle results.

Correlation between size and CSP in Sweden is more clear and stronger. Top 5 banks from the sample scored much higher than the average index. Such differences in results between Ukrainian and Swedish banks could be explained by lower social initiatives in the countries and attitude of the banks management to CSR.

Next stage of the research was in checking the adequacy of the index through the comparing to the already made professional indexes. On this stage it became clear that choosing Swedish banks for this purpose was not so good idea. The only index that is in open access and which we've got is Folksam sustainability index. But this index counts company's performance separately by two parameters: environmental performance and human rights protection (table 5).

Table 5. Folksam CSR index

\begin{tabular}{|l|c|c|c|c|}
\hline \multirow{2}{*}{ Name } & \multicolumn{2}{|c|}{ Folksam 2011 } & \multirow{2}{*}{ Our CSR Index } \\
\cline { 2 - 5 } & Environmental perfomance & Human rights protection & Average & \\
\hline Swedbank & 4,78 & 4,41 & 4,595 & 19 \\
\hline Handelsbanken & 4,48 & 4,62 & 4,55 & 20 \\
\hline SEB & 3,85 & 4,48 & 4,165 & 21 \\
\hline Nordea & 3,69 & 4,48 & 4,085 & 21 \\
\hline Nordnet & 2,05 & 1,72 & 1,885 & 13 \\
\hline Avanza & 0,35 & 1,23 & 0,79 & 15 \\
\hline
\end{tabular}

\footnotetext{
${ }^{7}$ According to data of http://www.swedishbankers.se
} 
It is evident that according two indexes top 4 banks scored good, but their ranks according Folksam do not match scorings according our index. This is simple to explain. We've analyses much wider sample of parameters and aspects of CSR so for checking our index for adequacy we need to get more complex index of CSR.

\section{Conclusions}

The objective of our paper was to solve a problem of CSR performance measurement in Ukrainian financial market. The point is that there was no index or other benchmark of the CSR in Ukraine earlier. Thus, to have more or less clear picture we decided to develop our own index of CSR so this work became the first ever made attempt to evaluate CSP in the region. As a basis for our CSR index was chosen one of the most fundamental and most cited works in this sphere - "The Pyramid of Corporate Social Responsibility: Toward the Moral Management of Organizational Stakeholders" by A. Carroll. According to this paper and other works in the field of CSR we've substantiated and picked up 25 indicators, which as we believe, reflect CSR in the bank most of all. Those indicators were divided into groups according to the CSR pyramid and moral management approach for better understanding of theirs nature.

In the research we've analyzed 40 banks which operate on Ukrainian market (17 "resident banks" and 23 with foreign capital). To calculate the final index of CSR we've summarized all indicators taken for our research. Afterwards we've analyzed a sample of Swedish banks to compare their index scorings with the existing professionally made indexes of CSR.

The results of the analysis on Ukrainian banks occurred controversial. During our investigation 3 hypotheses were made. The first hypothesis supposed that there is a correlation between the size of the bank and its CSR index as in Ukraine so in Sweden. We found some correlation between the size of the bank and its corporate social performance (CSP) but it is not homogeneous and could not be taken as an absolute. It was partially approved because the majority of bigger banks showed better results, but some of them failed to score higher than average and some smaller banks showed results mush higher than each of biggest banks. At the same time correlation between size and CSP in Sweden is more clear and stronger. Top 5 banks from the sample scored much higher than the average index. Such differences in results between Ukrainian and Swedish banks could be explained by lower social initiatives in the countries and attitude of the banks management to CSR.

The second hypothesis about differences in CSP of resident and nonresident Ukrainian banks was confirmed. But we should admit, that the majority of nonresident banks are in top 20 ranked by size. And there is no possibility on this stage of the research to indicate which factor influences banks' CSP more: size or residence. But we conclude that both these factors in synergy made their contribution into the final result.

Finally, our last hypothesis predicted that Ukrainian banks will score lower in CSR index than Swedish banks. The hypothesis was proved. As we expected, the average CSR index for Ukrainian banks stood at "10" points, while Swedish banks got "16" as an average.

Though all hypotheses were proved, it is still arguable weather such methodology can be taken as an absolute for Ukrainian banks. The main problem is rather declarative character of CSR activities in 
Ukrainian banks. Besides, it has been concluded from the researches that checking the adequacy of our index by comparing it with professional indexes was not as successful as we expected. The only index on which we could get data -Folksam CSR index did not match our CSR bank ranking. Though, it can be explained by much wider sample of indicators taken by us, than while calculating Folksam CSR index. It also leaves an open question about the correlation between CSR and CFP of the banks and further improvement of the CSR index for Ukrainian financial institutions. That leaves a space for new more in depth researches in this field of study.

\section{References}

1. Alexander, J. (1997) 'On the Right Side', World Business, 3(1) Jan/Feb: 38-41.

2. Banking supervision data of the National Bank of Ukraine: http://www.bank.gov.ua

3. Banks performance indicators, Ukrainian Banking Association: http://aub.org.ua/

4. BATCCA Chair on Social Business and Corporate Social Responsibility, Manual of Corporate Social Responsibility Indicators. INCAE's Comprehensive Model, 2009

5. Carroll A. "The Pyramid of Corporate Social Responsibility: Toward the Moral Management of Organizational Stakeholders", Business Horizons, July-August 1991.

6. D'Amato A., Henderson S., Florence S. (2007), “Corporate Social Responsibility and Sustainable business. Tasks and Functions”, Center for Creative Leadership Greensboro, North Carolina

7. Dickerson, C. and Hagen, K. (1998) 'Corporate Codes of Conduct', American Society of International Law, Proceedings of the Annual Meeting, Washington: 265-277.

8. Diller, J. (1999) 'A Social Conscience in the Global Marketplace? Labor Dimensions of Codes of Conduct, Social Labeling and Investor Initiatives', International Labor Review, 138(2): 99-129.

9. Dimtcheva L, Marsland G., Morrison J. (2002) "Boxing against Green Shadows. Creation of a shadow benchmark makes SRI portfolios more efficient and easier to manage”, Portfolio \& Risk Advisory, 19 July 2002.

10. Freeman R. E. (1984): "Strategic Management: a Stakeholder Approach". Pitman, Boston.

11. Friedman, M., (1970), "The Social Responsibility of Business Is to Increase its Profits", New York Times Magazine, September 13, 122-126.

12. Gordon K. (2001) «The OECD Guidelines and Other Corporate Responsibility Instruments: A Comparison», OECD Directorate for Financial, Fiscal and Enterprise Affairs. www.oecd.org/dataoecd/46/36/2075173.pdf (08 March 2002).

13. Griffin, J.J. and Mahon, J.F., (1997), "The corporate social performance and corporate financial performance debate: Twenty-five years of incomparable research", Business and Society, 36, 5-31.

14. Guidance on corporate responsibility indicators in annual reports (2008), UNCTAD, New York and Geneva

15. Hurst E. (2004) "Corporate Ethics, Governance and Social Responsibility: Comparing European Business Practices to those in the United States", A Study Conducted for the Business and 
Organizational Ethics Partnership Markkula Center for Applied Ethics Santa Clara University, Spring 2004.

16. Kaptein, M, and Wempe, J. (2002) The Balanced Company: A Theory of Corporate Integrity, Oxford University Press: Oxford.

17. Kolk, A. van Tulder, R. and Welters, C. (1999) 'International Codes of Conduct and Corporate Social Responsibility: Can Transnational Corporations Regulate Themselves?' Transnational Corporations, 8(1): 143-180.Kytle B., Gerard Ruggie J. (2005), "Corporate Social Responsibility as Risk Management", A Working paper of the Corporate Social Responsibility Initiative, Harvard University

18. Levine, M.A. (2008), "The Benefits of Corporate Social Responsibility". New York Law Journal. August 13.

19. Maria-Gaia Soana (2010), “Corporate social responsibility and financial performance: evidence from the financial sector", Available at SSRN: http://ssrn.com/abstract=1325956

20. McWilliams, A and Siegel, D 2000, 'Research notes and communications. Corporate social responsibility and financial performance: correlation or misspecification?', Strategic Management Journal, vol 21, pp 603-9.

21. Mitchell C., Holt D., Swartz R., Kido A., Song J., Kolind K. (2004), "Measuring sustainability”, UNC Kenan-Flagler, Octover 15, 2004.

22. Rey, M and Nguyen, T 2005, Financial payback from environmental \& social factors, AMP Capital Investors, April, Sydney.

23. Sacconi L., (2004) Corporate Social Responsibility as a Model of "Extended" Corporate Governance. An Explanation based on the Economic Theories of Social Contract, Reputation and Reciprocal Conformism, Liuc Papers n. 142, Serie Etica, Diritto ed Economia 10, suppl.

24. United States Council for International Business (2000) Corporate Codes of Conduct: Overview and Summary of Initiatives, United States Council for International Business. www.uscib.org/index.asp?documentID=1434 (17 March 2004) 
Appendix 1

Parameters of the CSR index

\begin{tabular}{|c|c|}
\hline Group name/ parameter name & Marking \\
\hline Economic Components (Responsibilities) & $E^{c}$ \\
\hline - profit & $p$ \\
\hline - $\quad$ dividends paid & $d^{p}$ \\
\hline - $\quad$ taxes paid & $t^{p}$ \\
\hline Legal Components (Responsibilities) & $L^{c}$ \\
\hline - $\quad$ regulative compliance & $r^{c}$ \\
\hline - law obedience & $l^{o}$ \\
\hline Ethical Components (Responsibilities) & $E t h^{c}$ \\
\hline - $\quad$ socially responsible investments & $I^{r}$ \\
\hline - expenditures on 1 employee higher than average & $E x>a v$ \\
\hline - $\quad$ employee support programs & esp \\
\hline $\begin{array}{ll}- & \text { environmental responsibility }\end{array}$ & $E n^{r}$ \\
\hline - $\quad$ remuneration disclosure & $D^{r}$ \\
\hline - $\quad$ information on the board of directors & $D^{b d}$ \\
\hline - $\quad$ general disclosure to stakeholders & $D^{s t}$ \\
\hline - $\quad$ CSR report & $R^{c s r}$ \\
\hline - $\quad$ GRI comppliance (or similar) & $C^{G R I}$ \\
\hline Philanthropic Components (Responsibilities) & $P h^{r}$ \\
\hline - $\quad$ philanthropic activity & $p h$ \\
\hline - $\quad$ arts support & $a r t^{s}$ \\
\hline $\begin{array}{ll}\text { - } & \text { education support }\end{array}$ & $e d^{s}$ \\
\hline - $\quad$ employees volunteering activity & $v a^{e m p}$ \\
\hline Moral management components (Responsibilities) & $M M^{c}$ \\
\hline - $\quad$ independent directors in the board & $D^{i}$ \\
\hline - $\quad$ committees of the board & $C^{b}$ \\
\hline - $\quad$ audit committee & $C^{a}$ \\
\hline - CSR committee & $C^{c s r}$ \\
\hline - corporate governance committee & $C^{c g}$ \\
\hline - $\quad$ code of conduct & $C^{c}$ \\
\hline CSR development & $C S R^{d}$ \\
\hline
\end{tabular}


Appendix 2

Results on CSR index (Ukrainian banks)

\begin{tabular}{|c|c|c|c|}
\hline № & Size & Name & CSR Index \\
\hline 1 & 1 & Privatbank & 11 \\
\hline 2 & 2 & Oshadbank & 8 \\
\hline 3 & 3 & Ukreximbank & 13 \\
\hline 4 & 4 & Raiffeisenbank Aval & 14 \\
\hline 5 & 5 & Ukrsybbank & 11 \\
\hline 6 & 6 & Ukrsocbank & 13 \\
\hline 7 & 7 & Prominvestbank & 10 \\
\hline 8 & 8 & OTP Bank & 11 \\
\hline 9 & 9 & VTB bank & 14 \\
\hline 10 & 10 & Alfa bank & 10 \\
\hline 11 & 11 & Nadra & 15 \\
\hline 12 & 12 & Finansy ta Kredyt & 15 \\
\hline 13 & 13 & Forum & 13 \\
\hline 14 & 14 & PUMB & 11 \\
\hline 15 & 15 & Rodovid bank & 5 \\
\hline 16 & 17 & Swedbank & 11 \\
\hline 17 & 18 & Kreditprombank & 9 \\
\hline 18 & 19 & Ukrgasbank & 9 \\
\hline 19 & 21 & ING bank & 8 \\
\hline 20 & 22 & Universal bank & 8 \\
\hline 21 & 23 & Unicredit & 15 \\
\hline 22 & 24 & Erste & 14 \\
\hline 23 & 25 & Delta & 8 \\
\hline 24 & 26 & Pravex & 6 \\
\hline 25 & 27 & VAB & 13 \\
\hline 26 & 29 & Chreshatyk & 7 \\
\hline 27 & 30 & Sberbank & 8 \\
\hline 28 & 32 & Index bank & 8 \\
\hline 29 & 33 & Kredobank & 4 \\
\hline 30 & 34 & Finansova iniciatyva & 5 \\
\hline 31 & 35 & Morfinbank & 11 \\
\hline 32 & 40 & Kyiv & 8 \\
\hline 33 & 50 & Express bank & 7 \\
\hline 34 & 51 & Tavryka & 10 \\
\hline 35 & 52 & Ukrajinskyy profesiynyy bank & 7 \\
\hline 36 & 53 & Ekspobank & 6 \\
\hline 37 & 54 & Aktyvbank & 10 \\
\hline 38 & 57 & Ukrinbank & 10 \\
\hline 39 & 58 & Diamant & 11 \\
\hline 40 & 59 & Evrogasbank & 7 \\
\hline
\end{tabular}

Corporate Social Responsibility Index For Ukrainian Banks: The Essentials For Implementation [Text] / O. Kostyuk, O. Kostyuk, Y. Mozghovyi, Y. Kravchenko // Corporate Ownership and Control. - Vol. 11, issue 4. - 2013. - P. 434-445. 